\title{
A Phenol-Based Compartmental Ligand as a Potential Chemosensor for Zinc(II) Cations
}

\author{
Jingwen Chen, ${ }^{a, b}$ Shuhong Cao, ${ }^{b}$ Dandan Wang, ${ }^{b}$ Shengde Wu ${ }^{b}$ and Xiaoyong Wang ${ }^{*, a}$ \\ ${ }^{a}$ State Key Laboratory of Pharmaceutical Biotechnology, School of Life Sciences, Nanjing University, \\ Nanjing 210093, P.R. China \\ ${ }^{b}$ School of Chemical and Biological Engineering, Yancheng Institute of Technology, Yancheng 224051, P.R. China
}

\begin{abstract}
O ligante compartimental 2,6-bis(2-hidroxibenzil-2-hidroxietilamino) metil-4-metilfenol (L) foi sintetizado como um sensor químico em potencial para íons $\mathrm{Zn}^{2+}$. A base $\mathbf{L}$ coordena dois cátions $\mathrm{Zn}^{2+}$ em metanol-água, formando um complexo dinuclear cuja formulação foi confirmada por espectrometria de massas com ionização por "electrospray" (ESI-MS) e pelo gráfico de Job. A fluorescência de $\mathbf{L}$ é notavelmente aumentada por $\mathrm{Zn}^{2+}$ em comparação com os íons $\mathrm{K}^{+}, \mathrm{Ca}^{2+}$, $\mathrm{Mg}^{2+}, \mathrm{Cu}^{2+}, \mathrm{Pb}^{2+}, \mathrm{Mn}^{2+}, \mathrm{Fe}^{3+}, \mathrm{Fe}^{2+}, \mathrm{Co}^{2+}, \mathrm{Cd}^{2+} \mathrm{e} \mathrm{Ni}^{2+}$. Isto se deve ao fato de que a complexação do íon $\mathrm{Zn}^{2+}$ a $\mathbf{L}$ interrompe o processo de transferência eletrônica fotoinduzida e aumenta a rigidez do esqueleto molecular de $\mathbf{L}$. Observou-se ainda que a fluorescência de $\mathbf{L}$ é fortemente dependente da acidez e da polaridade dos solventes. Este composto poderá ser utilizado como uma sonda sensível a íons $\mathrm{Zn}^{2+}$ em solventes polares próticos, após uma modificação estrutural adequada.
\end{abstract}

An "end-off"-type compartmental Lewis base, 2,6-bis(2-hydroxybenzyl-2-hydroxyethylamino) methyl-4-methylphenol (L), was synthesized as a potential chemosensor for $\mathrm{Zn}^{2+}$ ions. $\mathbf{L}$ coordinates two $\mathrm{Zn}^{2+}$ cations in methanol-water solution, forming a dinuclear complex whose formulation was confirmed by ESI-MS spectroscopy and Job's plot. The fluorescence of $\mathbf{L}$ is remarkably enhanced by $\mathrm{Zn}^{2+}$ as compared with $\mathrm{K}^{+}, \mathrm{Ca}^{2+}, \mathrm{Mg}^{2+}, \mathrm{Cu}^{2+}, \mathrm{Pb}^{2+}, \mathrm{Mn}^{2+}, \mathrm{Fe}^{3+}, \mathrm{Fe}^{2+}, \mathrm{Co}^{2+}, \mathrm{Cd}^{2+}$ and $\mathrm{Ni}^{2+}$ ions. The fluorescence enhancement is attributed to the complexation of $\mathrm{Zn}^{2+}$ with $\mathbf{L}$, which interrupts the photoinduced electron transfer process and rigidifies the molecular skeleton of $\mathbf{L}$. The fluorescence of $\mathbf{L}$ is greatly dependent on the acidity and polarity of the solvents. This compound may be used as a probe to sense $\mathrm{Zn}^{2+}$ ion in polar protic solvents after proper modification.

Keywords: chemosensor, fluorescence mechanism, phenol derivative, solvent effects, zinc(II)

\section{Introduction}

Zinc(II) ions play vital roles in a wide range of physiological processes. Deficiency or imbalance of $\mathrm{Zn}^{2+}$ within the human body can lead to a variety of diseases. ${ }^{1}$ Hence the development of selective zinc chemosensors is of great importance for tracking the $\mathrm{Zn}^{2+}$ status in biological systems. ${ }^{2}$ Fluorescence chemosensors based on photoinduced electron transfer (PET), ${ }^{3}$ intramolecular charge transfer (ICT), ${ }^{4}$ excited-state intramolecular proton transfer (ESIPT), ${ }^{5}$ and fluorescence resonance energy transfer (FRET) mechanisms have been developed for this purpose in the past years..$^{2,6-10}$ Nevertheless, none of them completely satisfies the criteria for a biosystemoriented chemosensor. Therefore, efforts to design novel zinc probes are still needed.

\footnotetext{
*e-mail: boxwxy@nju.edu.cn
}

Structural factors, such as molecular rigidity, could produce significant influence on the fluorescence efficiency of a chemosensor. An increase in planarity and a decrease in torsion may benefit the chemosensor to enhance its fluorescence. ${ }^{11}$ As a metal ion binds to a chemosensor, the molecular rigidity is enhanced and the above mentioned transfer processes are possibly inhibited, and thereby the fluorescence may arise. Based on such chelation enhanced fluorescence (CHEF) mechanism, many zinc chemosensors have been designed. ${ }^{12-16}$ The structure of a typical cation chemosensor is usually composed of two parts: an ion recognition and a signal transduction units. ${ }^{8}$ We herein report an atypical fluorescence chemosensor where only benzene rings act as fluorophores and alcoholic and phenolic hydroxyls as ion recognition units (Figure 1). This molecule displays selective chelation enhanced fluorescence in the presence 


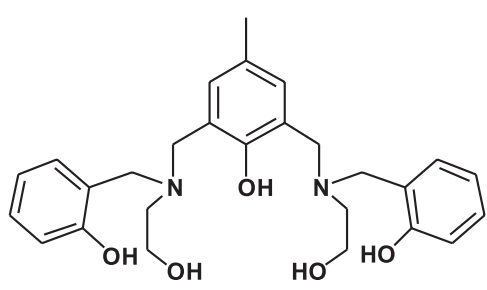

Figure 1. Representation of the chemical structure of compound $\mathbf{L}$.

of $\mathrm{Zn}^{2+}$ when compared to other common cations in HEPES-buffered methanol-water solution.

\section{Experimental}

\section{Materials and general methods}

All reagents and solvents, including 2-[4-(2hydroxyethyl)-1-piperazinyl]-ethanesulfonic acid (HEPES), were of analytical grade and used without further purification. The compound 2,6-bis(2-hydroxybenzyl2-hydroxyethylamino)methyl-4-methylphenol (L) was synthesized by a procedure reported for an analogue, except for minor modifications that we have described recently. ${ }^{17,18}$ The testing samples were prepared using newly doubledistilled water.

The infrared spectra were recorded on a Bruker VECTOR22 spectrometer as $\mathrm{KBr}$ pellets $\left(4000-500 \mathrm{~cm}^{-1}\right)$. Elemental $(\mathrm{C}, \mathrm{H}, \mathrm{N})$ analyses were performed on a Perkin-Elmer 240C analytic instrument. Electrospray mass spectra were recorded using an LCQ electron spray mass spectrometer (ESI-MS, Finnigan). The UV and fluorescence spectra were collected on a Shimadzu UV-2450 spectrophotometer and a Jasco FP-6500 spectrofluorometer equipped with a thermostated cell compartment, respectively. A quartz cuvette $(1.0 \mathrm{~cm}, 3.0 \mathrm{~mL})$ was used to carry out the spectroscopic titrations.

\section{UV and fluorescence spectrophotometric titrations}

The stock solution of $\mathbf{L}$ was prepared by dissolving $\mathbf{L}$ in a methanol-water solution (90/10, v/v) containing HEPES buffer (10 $\mathrm{mmol} \mathrm{L}^{-1}, \mathrm{pH} 7.40$ ). Aqueous solutions of $\mathrm{Zn}^{2+}$, $\mathrm{Mn}^{2+}, \mathrm{Co}^{2+}, \mathrm{Cu}^{2+}, \mathrm{Mg}^{2+}, \mathrm{Pb}^{2+}, \mathrm{Fe}^{2+}, \mathrm{Ca}^{2+}$ and $\mathrm{Ni}^{2+}$ were prepared from their acetate salts, and those of $\mathrm{K}^{+}, \mathrm{Fe}^{3+}$, and $\mathrm{Cd}^{2+}$ were prepared from the respective chlorides and an equimolar amount of sodium acetate. UV and fluorescence titrations were carried out by syringing aliquots $(10 \mu \mathrm{L})$ of the $\mathrm{Zn}^{2+}$ solution $\left(1 \mathrm{mmol} \mathrm{L}^{-1}\right)$ into that of $\mathbf{L}\left(50 \mu \mathrm{mol} \mathrm{L} \mathrm{L}^{-1}\right)$ in HEPES buffer $(3 \mathrm{~mL})$. After each addition, the mixture was equilibrated for $c a .5 \mathrm{~min}$. Fluorescence spectra were recorded in the range of $285-450 \mathrm{~nm}$ at $298 \mathrm{~K}$ with an excitation wavelength of $276 \mathrm{~nm}$. The variation of volumes for all titrations was restricted within $1 \%$ and the same HEPES buffer was used as a reference. The proportion of $\mathbf{L}$ and $\mathrm{Zn}^{2+}$ in the product was determined by Job's plot of the fluorescence data and was subsequently verified by ESI-MS spectroscopy.

\section{Results and Discussion}

\section{UV absorption and ESI-MS}

The UV spectra of $\mathbf{L}$ in HEPES-buffered methanolwater solution are presented in Figure 2. The characteristic absorption appears in the range of $250-320 \mathrm{~nm}$ with a $\lambda_{\text {max }}$ of $280 \mathrm{~nm}\left(\varepsilon=4.93 \times 10^{3} \mathrm{~L} \mathrm{~mol}^{-1} \mathrm{~cm}^{-1}\right)$, which could be assigned to the $\alpha$ band of the substituted phenyls. The absorbance of $\mathbf{L}$ decreases and the $\lambda_{\text {max }}$ shifts to $282 \mathrm{~nm}$ $\left(\varepsilon=4.52 \times 10^{3} \mathrm{~L} \mathrm{~mol}^{-1} \mathrm{~cm}^{-1}\right)$ upon addition of $\mathrm{Zn}^{2+}$ to $\mathbf{L}$ for the formation of $-\mathrm{O}^{-}$. The red-shift of the $\lambda_{\text {max }}$ is indicative of the coordination involving the phenolic oxygen donors and $\mathrm{Zn}^{2+}{ }^{19}$ The maximum absorption stops decreasing when the ratio of $\mathrm{Zn}^{2+}$ to $\mathbf{L}$ approaches 2, suggesting that a 1:2 dinuclear $\mathbf{L}-\mathrm{Zn}^{\mathrm{II}}$ complex is formed. Two isosbestic points at 257 and $284 \mathrm{~nm}$ are observed, which suggest the existence of an equilibrium between $\mathbf{L}$ and $\mathbf{L}-\mathrm{Zn}^{\text {II }}$. From the absorption profile, the binding constant is calculated to be $2.06 \times 10^{4} \mathrm{~L} \mathrm{~mol}^{-1}$, following the reported equation. ${ }^{20}$

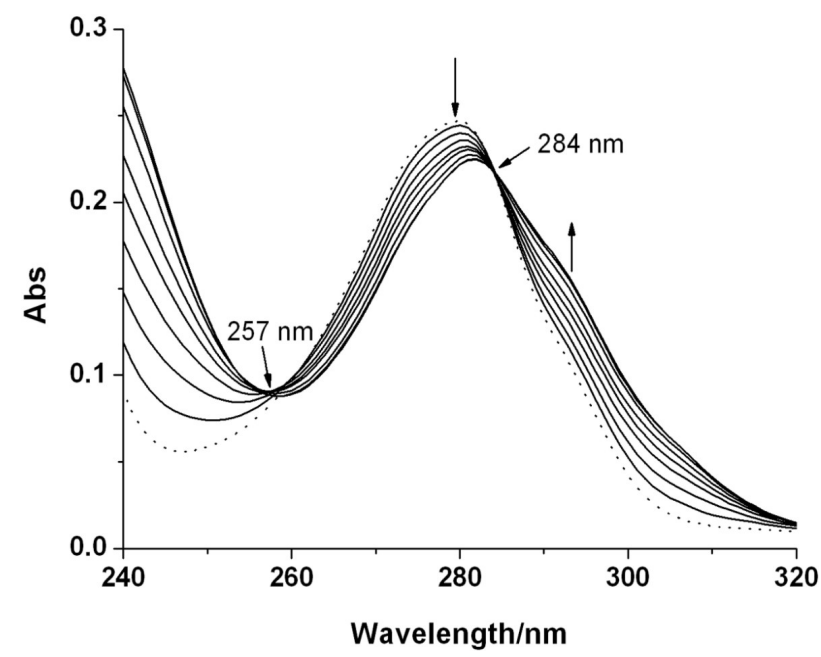

Figure 2. UV absorption profiles of $\mathbf{L}\left(50 \mu \mathrm{mol} \mathrm{L} \mathrm{L}^{-1}\right)$ after addition of $\mathrm{Zn}^{2+}$ (0-2.5 equivalents) in methanol-water solution $(90 / 10, \mathrm{v} / \mathrm{v})$ containing HEPES buffer (10 $\left.\mathrm{mmol} \mathrm{L}^{-1}, \mathrm{pH} 7.40\right)$ at $298 \mathrm{~K}$.

The ESI-MS spectrum obtained with the solution containing $\mathbf{L}$ and $\mathrm{Zn}^{2+}$ in a ratio of 1:2 also supports the formation of the dinuclear complex (Figure 3 ). The peak at $\mathrm{m} / \mathrm{z} 593.3$ corresponds to one positively charged dinuclear 


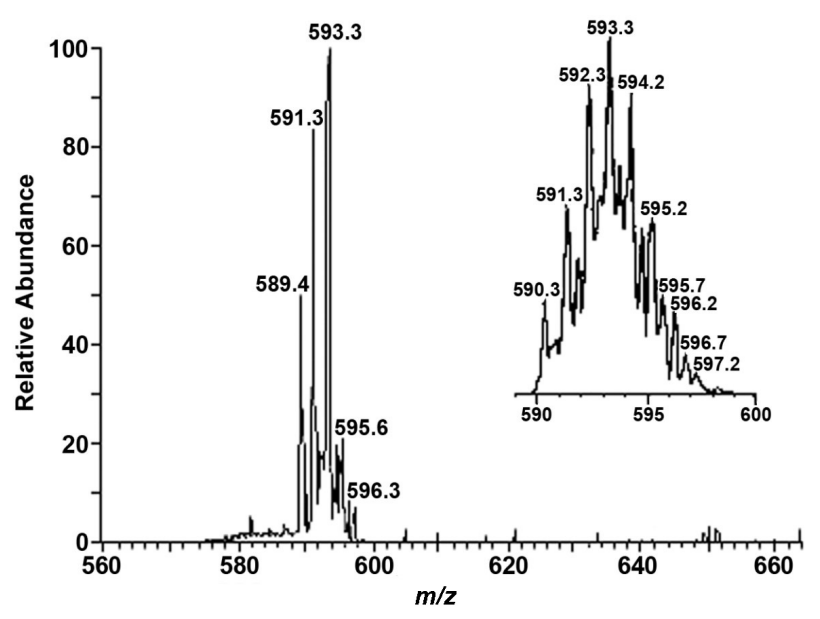

Figure 3. ESI-MS spectrum (positive mode) for the dinuclear $\mathbf{L}-\mathrm{Zn}^{\mathrm{II}}$ complex prepared in situ in methanol-water solution $(90 / 10, v / v)$ at $298 \mathrm{~K}$.

species $\left[\mathrm{Zn}_{2}(\mathbf{L}-3 \mathrm{H})\right]^{+}$, which agrees with the result of the UV spectra. Thus, a possible structure for the $\mathbf{L}-\mathrm{Zn}^{\mathrm{II}}$ complex can be proposed in Figure 4. In this structure, $\mathbf{L}$ provides a $\mathrm{NO}_{3}$ donor set, i.e. an amine- $\mathrm{N}$, an alcoholic-O, a phenolic-O, and a bridging cresolic- $\mathrm{O}$, for each $\mathrm{Zn}^{2+}$ ion. Considering the coordination number of $\mathrm{Zn}^{2+}$, a bridging carboxyl group and one or two water molecules may be involved in the metal coordination sphere, which resembles the structure we reported previously for a similar complex. ${ }^{17}$

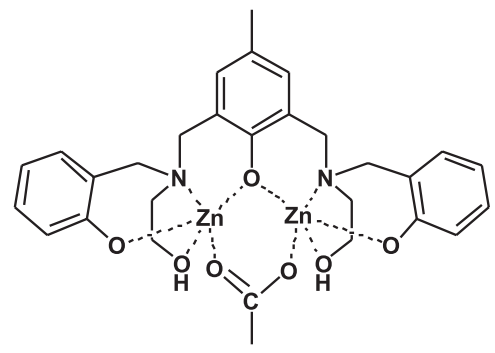

Figure 4. Proposed structure for the dinuclear $\mathbf{L}-\mathrm{Zn}^{\mathrm{II}}$ complex. Charges, counter ions, and possible water molecules are omitted for clarity.

Fluorescence response of $\boldsymbol{L}$ to zinc(II)

Compound $\mathbf{L}$ exhibits moderate fluorescence with a $\lambda_{\text {em }}$ of $308 \mathrm{~nm}$ when excited at $276 \mathrm{~nm}$ in HEPESbuffered methanol-water solution. Upon addition of $\mathrm{Zn}^{2+}$ $\left(50 \mu \mathrm{mol} \mathrm{L}{ }^{-1}\right)$, the fluorescence intensity of $\mathbf{L}$ increases proportionally until the molar ratio of $\mathrm{Zn}^{2+}$ to $\mathbf{L}$ reaches 2.5 (Figure 5, inset). The result is basically in agreement with that of the UV titrations. The Stokes shift is about $30 \mathrm{~nm}$ and no significant change is observed for the position of $\lambda_{\mathrm{ex}}$ and $\lambda_{\mathrm{em}}$. The Job's plot based on the fluorescence intensity of $\mathbf{L}-\mathrm{Zn}^{\mathrm{II}}$ is presented in Figure 6, which confirms that the proportion of $\mathbf{L}: \mathrm{Zn}^{2+}$ is $c a .1: 2$.

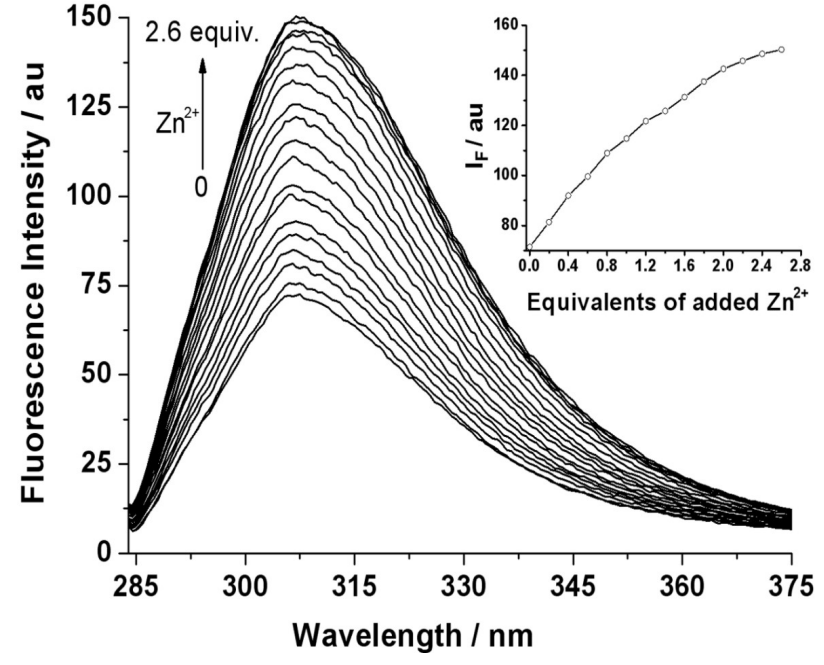

Figure 5. Fluorescence enhancement of $\mathbf{L}\left(50 \mu \mathrm{mol} \mathrm{L}^{-1}\right)$ with increasing amount of $\mathrm{Zn}^{2+}$ in HEPES-buffered (10 $\mathrm{mmol} \mathrm{L}^{-1}$, $\mathrm{pH}$ 7.40) methanolwater solution $\left(90 / 10, \mathrm{v} / \mathrm{v}\right.$ ) at $298 \mathrm{~K}$. $\lambda_{\mathrm{ex}}: 276 \mathrm{~nm} ; \mathrm{Zn}^{2+}$ (from bottom to top): $0,10,20,30,40,50,60,70,80,90,100,110,120$ and $130 \mu \mathrm{mol} \mathrm{L}^{-1}$; Inset: fluorescence intensity $\left(\mathrm{I}_{\mathrm{F}}\right)$ changes of $\mathbf{L}$ at $308 \mathrm{~nm}$.

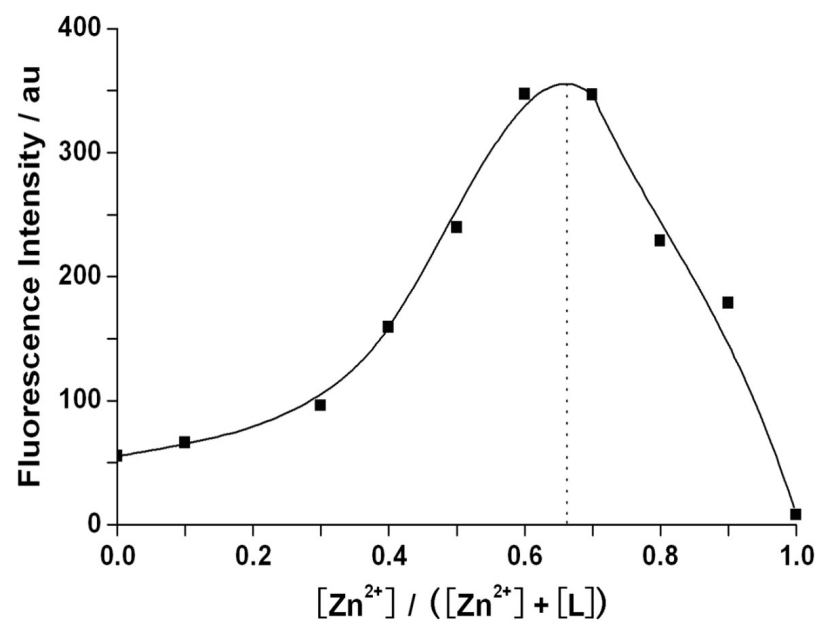

Figure 6. Job's plot for the fluorescence of the $\mathbf{L}-\mathrm{Zn}^{\mathrm{II}}$ system at $308 \mathrm{~nm}$ in HEPES-buffered (10 mmol L-1, pH 7.40) methanol-water solution (90/10, v/v). $\left[\mathbf{L}+\mathrm{Zn}^{2+}\right]=100 \mu \mathrm{mol} \mathrm{L} \mathrm{L}^{-1} ; \lambda_{\text {ex }}=276 \mathrm{~nm}$.

It is known that rigid conjugate structures tend to generate strong fluorescence, ${ }^{21,22}$ and that $\mathrm{H}^{+}, \mathrm{OH}^{-}$and $\mathrm{H}_{2} \mathrm{O}$ molecules in solution are capable of forming effective hydrogen bonds with the donor groups of a chromophore in the ground and excited states. ${ }^{23}$ Therefore, $\mathbf{L}$ may form hydrogen bonds with $\mathrm{H}^{+}, \mathrm{OH}^{-}$and/or $\mathrm{H}_{2} \mathrm{O}$ in solution; $\mathbf{L}$ may also form intra- or intermolecular hydrogen bonds via its three phenolic and two alcoholic hydroxyl groups. Such hydrogen bonds can enhance the rigidity of $\mathbf{L}$ and thereby contribute to the moderate fluorescence of $\mathbf{L}$ in solution.

A cooperative host-guest complexation can increase the rigidity of the host conformation and hence enhance its fluorescence. ${ }^{24}$ Upon coordination with $\mathrm{Zn}^{2+}$, hydrogen 
bonds within or between $\mathbf{L}(\mathrm{s})$ are broken and the torsion of the alcoholic hydroxyl and the pendant phenol groups is confined. The cresolic-O bridging, coupled with exogenous acetate bridges, further restrict the twist of these groups. Thus, the rigidity of $\mathbf{L}$ is increased and its fluorescence is enhanced. However, because the phenyls in $\mathbf{L}$ are isolated by the alkyl linkers, the rigidization of $\mathbf{L}$ does not prompt conjugation all over the molecule. In this case, a simple interruption of the PET process from the tertiary amino groups to the phenolic moiety appears to be more likely. ${ }^{25}$

\section{Effect of acidity on the fluorescence}

The pH-dependent fluorescence of $\mathbf{L}$ and $\mathbf{L}-\mathrm{Zn}^{\mathrm{II}}$ prepared in situ was further investigated to verify the fluorescence mechanism. The $\mathrm{pH}$ value of both solutions was adjusted using $\mathrm{HCl}$ or $\mathrm{KOH}\left(10 \mathrm{mmol} \mathrm{L}^{-1}\right)$ and the alterations of the fluorescence at $308 \mathrm{~nm}$ were recorded in the range of $\mathrm{pH} 2-12$. As shown in Figure 7, both $\mathbf{L}$ and $\mathbf{L}-\mathrm{Zn}^{\mathrm{II}}$ show moderate fluorescence at low $\mathrm{pH}$ values. The fluorescence of $\mathbf{L}$ decreases with the increase of $\mathrm{pH}$ gradually before 10 and drastically after that. The reason for this may be the protonation of the tertiary amino $\mathrm{N}$ of $\mathbf{L}$ at low $\mathrm{pH}$ and the deprotonation of the phenolic $\mathrm{OH}$ and protonated tertiary amino $\mathrm{N}$ at high $\mathrm{pH}$; the former can interrupt the PET pathway from $\mathrm{N}$ atoms to phenolic moieties, while the latter can promote the PET process. For the $\mathbf{L}-\mathrm{Zn}^{\mathrm{II}}$ system, the fluorescence behavior resembles that of $\mathbf{L}$ when $\mathrm{pH}$ is below 4.0, suggesting the complex is not yet formed. However, the fluorescence at $308 \mathrm{~nm}$ increases significantly when $\mathrm{pH}$ is above 4.0 and reaches its maximum at $c a$. 8.0, which is about 3 times stronger than that of $\mathbf{L}$. The result suggests that the tertiary amino $\mathrm{N}$ has coordinated to $\mathrm{Zn}^{2+}$ and the PET process is inhibited.
The fluorescence of $\mathbf{L}-\mathrm{Zn}^{\mathrm{II}}$ decreases dramatically after $\mathrm{pH}$ 8.0, which may result from the hydrolysis of $\mathrm{Zn}^{2+}$ and the recovery of the PET process. Taken together, the fluorescence enhancement of $\mathbf{L}$ in the presence of $\mathrm{Zn}^{2+}$ involves not only the rigidization of the molecular skeleton but also the inhibition of the PET process.

\section{Effect of solvents on the fluorescence}

Solvent properties such as polarity and acidity can exert great influence on the fluorescence of a molecule. ${ }^{12}$ To gain a deeper insight into the fluorescence mechanism of $\mathbf{L}$ in the presence and absence of $\mathrm{Zn}^{2+}$, polar protic (e.g. water, methanol, ethanol) and polar aprotic (e.g. DMSO, acetonitrile) solvents were selected to examine their effects on the fluorescence. As Figure 8 shows, the fluorescence of $\mathbf{L}$ decreases remarkably with the increase of polarity and acidity in polar protic solvents. For example, the fluorescence is almost completely quenched in water in the absence or presence of $\mathrm{Zn}^{2+}$, which is similar to some reported chemosensors, ${ }^{23,26}$ however, the fluorescence is enhanced by $c a .3$ times in methanol and ethanol in the presence of $\mathrm{Zn}^{2+}$ with red shifts of 11.5 and $19 \mathrm{~nm}$ for the maximum emission, respectively. By contrast with this, only subtle changes in fluorescence and curve profile of $\mathbf{L}$ are observed in polar aprotic solvents, where $\mathrm{Zn}^{2+}$ has little influence on the fluorescence. It has been proved that the solvent polarity can affect the electron transfer of a fluorescence sensor. Polar protic solvents may act as carriers to facilitate the electron transfer through the partialpositively charged H-end. ${ }^{23}$ Thus, the electron transfer process from the tertiary amino $\mathrm{N}$ to the phenolic moiety is accelerated and the fluorescence is quenched. Moreover, polar protic solvents may facilitate $\mathbf{L}$ to form intra- and intermolecular hydrogen bonds. If the intermolecular
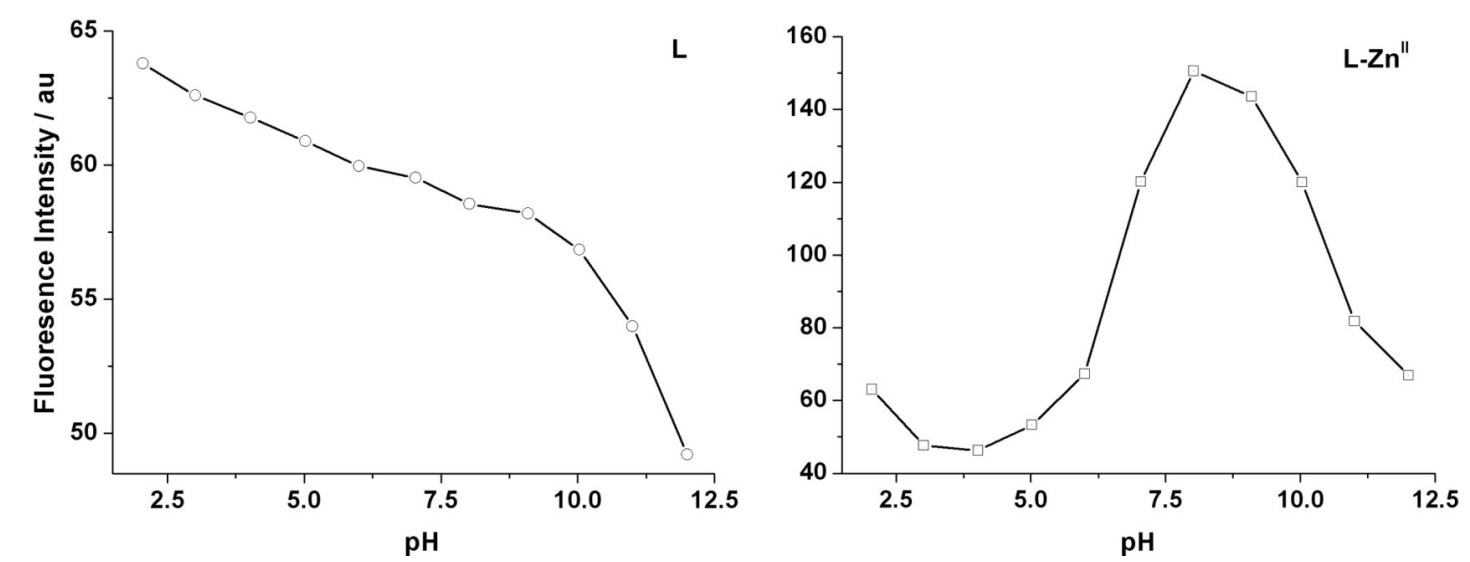

Figure 7. Effect of $\mathrm{pH}$ on the fluorescence of $\mathbf{L}\left(50 \mu \mathrm{mol} \mathrm{L} \mathrm{L}^{-1}\right.$, left $)$ and $\mathbf{L}-\mathrm{Zn}^{\mathrm{II}}$ prepared in situ $\left(50 \mu \mathrm{mol} \mathrm{L} \mathrm{L}^{-1}\right.$, right $)$ at $308 \mathrm{~nm}$ in methanol-water solution $(90 / 10, v / v)$ at $298 \mathrm{~K}\left(\lambda_{\text {ex }}=276 \mathrm{~nm}\right)$. 

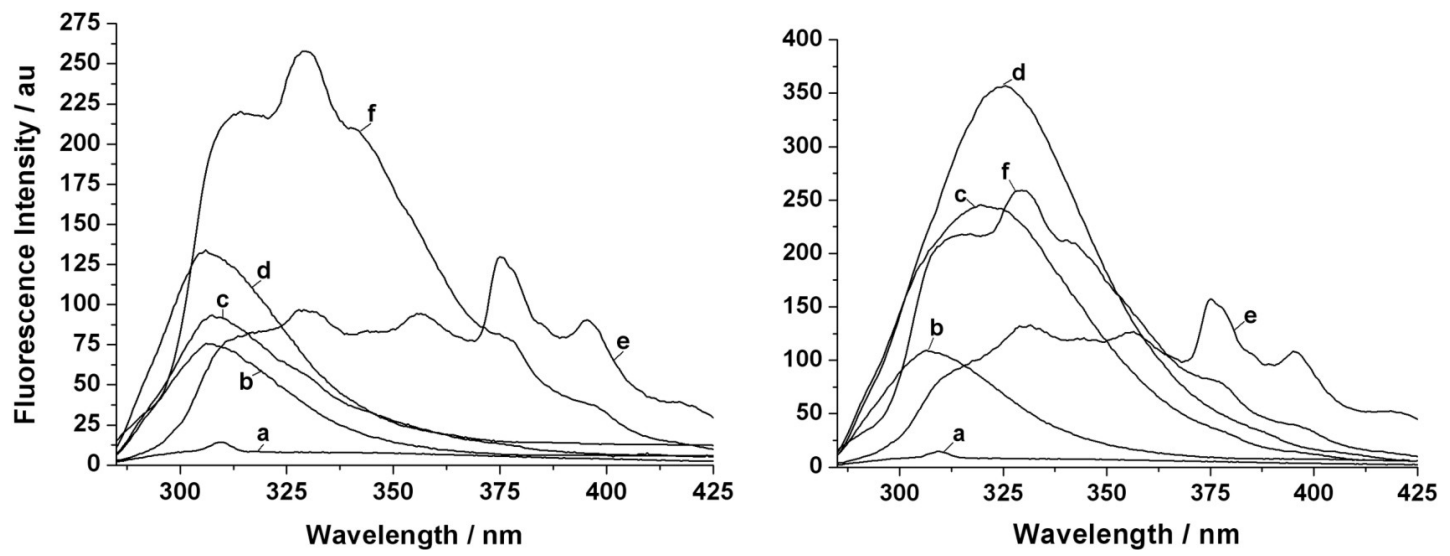

Figure 8. Fluorescence changes of $\mathbf{L}\left(50 \mu \mathrm{mol} \mathrm{L}^{-1}\right)$ in different solvents at $298 \mathrm{~K}$ in the absence (left) and presence (right) of $\mathrm{Zn}^{2+}(50 \mu \mathrm{mol} \mathrm{L}-1)$. (a) $\mathrm{H}_{2} \mathrm{O}$; (b) $\mathrm{MeOH} / \mathrm{H}_{2} \mathrm{O}(90 / 10, \mathrm{v} / \mathrm{v})$; (c) $\mathrm{MeOH}$; d, EtOH; (e) DMSO; (f) $\mathrm{CH}_{3} \mathrm{CN}$.

hydrogen bond is preferable, the rigidity of $\mathbf{L}$ would be weakened. Anyway, the suppression of the PET process and the rigidization of $\mathbf{L}$ appear to be the main reasons for the fluorescence of $\mathbf{L}$ and $\mathbf{L}-\mathrm{Zn}^{\mathrm{II}}$.

\section{Fluorescence responses of $\boldsymbol{L}$ to other cations}

Cations such as $\mathrm{K}^{+}, \mathrm{Ca}^{2+}, \mathrm{Mg}^{2+}, \mathrm{Cu}^{2+}, \mathrm{Pb}^{2+}, \mathrm{Mn}^{2+}$, $\mathrm{Fe}^{3+}, \mathrm{Fe}^{2+}, \mathrm{Co}^{2+}, \mathrm{Cd}^{2+}$ and $\mathrm{Ni}^{2+}$ were used instead of $\mathrm{Zn}^{2+}$ to investigate the fluorescence responses of $\mathbf{L}$ under the same condition. The fluorescence of $\mathbf{L}$ was evaluated by recording its changes after addition of the metal ion to the methanol-water solution of $\mathbf{L}$. To avoid possible hydrolysis and ensure the main reaction, the metal ion solution was added dropwise to $\mathbf{L}$ and the mixture was left for 5 min to reach the equilibrium. As Figure 9 shows, the alkali metal cation $\mathrm{K}^{+}$and the alkaline earth metal cations $\mathrm{Ca}^{2+}$ and

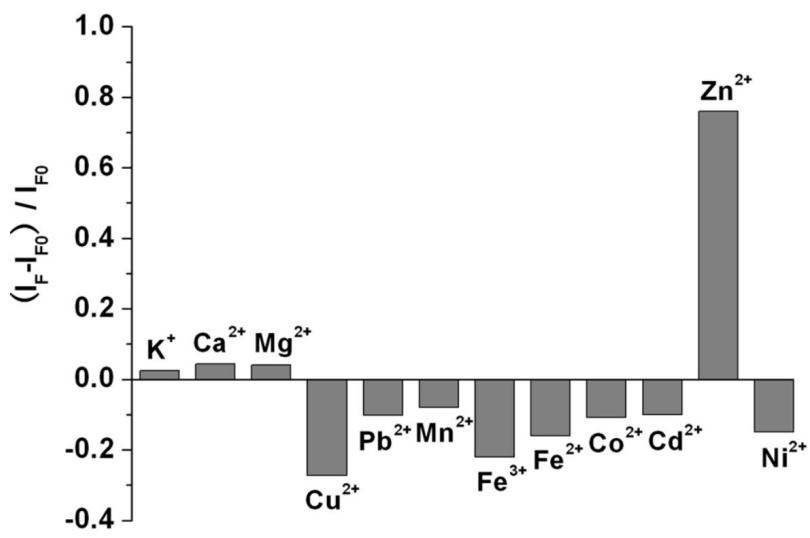

Figure 9. Fluorescence responses of $\mathbf{L}\left(50 \mu \mathrm{mol} \mathrm{L}^{-1}\right)$ to various metal ions in HEPES-buffered ( $\left.10 \mathrm{mmol} \mathrm{L}^{-1}, \mathrm{pH} 7.40\right)$ methanol-water solution $(90 / 10, v / v)$ at $298 \mathrm{~K}\left(\lambda_{\mathrm{ex}}=276 \mathrm{~nm} ; \lambda_{\mathrm{em}}=308 \mathrm{~nm}\right) . \mathrm{I}_{\mathrm{F}}$ and $\mathrm{I}_{\mathrm{F} 0}$ represent the fluorescence intensity of $\mathbf{L}$ in the presence and absence of cation, respectively.
$\mathrm{Mg}^{2+}$ hardly interfere with the fluorescence of $\mathbf{L}$ at high concentration $\left(5 \mathrm{mmol} \mathrm{L}^{-1}\right)$ due to their poor complexation with $\mathbf{L}$. However, the metal cations $\mathrm{Pb}^{2+}, \mathrm{Mn}^{2+}, \mathrm{Co}^{2+}, \mathrm{Ni}^{2+}$, and especially $\mathrm{Cu}^{2+}, \mathrm{Fe}^{3+}$, and $\mathrm{Fe}^{2+}$, reduce the fluorescence of $\mathbf{L}$ at relatively low concentration $\left(0.5 \mathrm{mmol} \mathrm{L}^{-1}\right)$, probably due to an electron or energy transfer between metal cation and L. ${ }^{12,27,28}$ Interestingly, $\mathrm{Cd}^{2+}$, that has the same $\mathrm{d}^{10}$ electronic configuration as $\mathrm{Zn}^{2+}$, does not enhance the fluorescence of $\mathbf{L}$. These observations indicate that $\mathbf{L}$ may selectively signal the presence of $\mathrm{Zn}^{2+}$ in methanolwater solution.

\section{Conclusions}

A phenol-based ligand (L) was synthesized as a potential chemosensor for $\mathrm{Zn}^{2+}$. A dizinc complex is formed by $\mathbf{L}$ and $\mathrm{Zn}^{2+}$ in methanol-water solution, which greatly enhances the fluorescence of $\mathbf{L}$. An inhibition of the PET process and a $\mathrm{Zn}^{\mathrm{II}}$-induced rigidization of $\mathbf{L}$ are suggested to account for the fluorescence enhancement. The fluorescence response of $\mathbf{L}$ to $\mathrm{Zn}^{2+}$ is more sensitive in polar protic solvents than in polar aprotic solvents. In similar conditions, $\mathbf{L}$ exhibits high fluorescence selectivity for $\mathrm{Zn}^{2+}$ over other common cations. The results suggest that $\mathbf{L}$ may possibly be used to sense $\mathrm{Zn}^{2+}$ after some structural modification.

\section{Acknowledgments}

We thank the financial support from the Natural Science Program for Basic Research of Higher Education of Jiangsu Province (Grant 06KJB150120), the China Postdoctoral Science Foundation (20060390918) and the Ministry of Education Foundation for New Teachers in Doctoral Programs (20070284065). 


\section{References}

1. Prasad, A. S.; Am. J. Clin. Nutr. 1991, 53, 403.

2. Ueno, S.; Tsukamoto, M.; Hirano, T.; Kikuchi, K.; Yamada, M. K.; Nishiyama, N.; Nagano, T.; Matsuki, N.; Ikegaya, Y.; J. Cell Biol. 2002, 158, 215.

3. Salman, H.; Tal, S.; Chuvilov, Y.; Solovey, O.; Abraham, Y.; Kapon, M.; Suwinska, K.; Eichen, Y.; Inorg. Chem. 2006, 45, 5315.

4. Maruyama, S.; Kikuchi, K.; Hirano, T.; Urano, Y.; Nagano, T.; J. Am. Chem. Soc. 2002, 124, 10650.

5. Henary, M. M.; Wu, Y. G.; Fahrni, C. J.; Chem.Eur. J. 2004, 10, 3015.

6. Godwin, H. A.; Berg, J. M.; J. Am. Chem. Soc. 1996, 118, 6514.

7. Woodroofe, C. C.; Lippard, S. J.; J. Am. Chem. Soc. 2003, 125, 11458.

8. Lim, N. C.; Freake, H. C.; Brückner, C.; Chem.-Eur. J. 2005, 11,38 .

9. Hendrickson, K. M.; Geue, J. P.; Wyness, O.; Lincoln, S. F.; Ward, A. D.; J. Am. Chem. Soc. 2003, 125, 3889.

10. Burdette, S. C.; Frederickson, C. J.; Bu, W.; Lippard, S. J.; J. Am. Chem. Soc. 2003, 125, 1778.

11. Radke, K. R.; Ogawa, K.; Rasmussen, S. C.; Org. Lett. 2005, 7, 5253.

12. De Silva, A. P.; Gunaratne, H. Q. N.; Gunnlaugsson, T.; Huxley, A. J. M.; McCoy, C. P.; Rademacher, J. T.; Rice, T. E.; Chem. Rev. 1997, 97, 1515.

13. Dai, Z.; Proni, G.; Mancheno, D.; Karimi, S.; Berova, N.; Canary, J. W.; J. Am. Chem. Soc. 2004, 126, 11760.
14. Royzen, M.; Durandin, A.; Young Jr., V. G.; Geacintov, N. E.; Canary, J. W.; J. Am. Chem. Soc. 2006, 128, 3854.

15. Pearce, D. A.; Jotterand, N.; Carrico, I. S.; Imperiali, B.; J. Am. Chem. Soc. 2001, 123, 5160.

16. Aoki, S.; Kaido, S.; Fujioka, H.; Kimura, E.; Inorg. Chem. 2003, 42, 1023.

17. Chen, J. W.; Wang, X. Y.; Zhu, Y. G.; Lin, J.; Yang, X. L.; Li, Y. Z.; Lu, Y.; Guo, Z. J.; Inorg. Chem. 2005, 44, 3422.

18. Chen, Z. F.; Wang, X. Y.; Chen, J. W.; Yang, X. L.; Li, Y. Z.; Guo, Z. J.; New J. Chem. 2007, 31, 357.

19. Balzani, V.; Scandola, F.; Supramolecular Photochemistry, Ellis Horwood: New York, 1991.

20. Pocker, Y.; Ciula, J. C.; J. Am. Chem. Soc. 1989, 111, 4728.

21. Nijegorodov, N. I.; Downey, W. S.; J. Phys. Chem. 1994, 98 , 5639.

22. Gao, L.; Wang, Y.; Wang, J.; Huang, L.; Shi, L.; Fan, X.; Zou, Z.; Yu, T.; Zhu, M.; Li, Z.; Inorg. Chem. 2006, 45, 6844.

23. Woo, H. Y.; Liu, B.; Kohler, B.; Korystov, D.; Mikhailovsky, A.; Bazan, G. C.; J. Am. Chem. Soc. 2005, 127, 14721.

24. Nakashima, H.; Yoshida, N.; Org. Lett. 2006, 8, 4997.

25. Valeur, B.; Leray, I.; Coord. Chem. Rev. 2000, 205, 3.

26. Woo, H. Y.; Hong, J. W.; Liu, B.; Mikhailovsky, A.; Korystov, D.; Bazan, G. C.; J. Am. Chem. Soc. 2005, 127, 820.

27. Hirano, T.; Kikuchi, K.; Urano, Y.; Higuchi, T.; Nagano, T.; Angew. Chem., Int. Ed. 2000, 39, 1052.

28. Mikata, Y. J.; Wakamatsu, M.; Yano, S.; Dalton Trans. 2005, 545.

Received: March 4, 2008

Web Release Date: October 15, 2008 